\title{
Pruning methods on the yield performance and oenological potential of 'Nebbiolo' grapevine
}

\author{
Ricardo Allebrandt(1), José Luiz Marcon Filho(2), Douglas André Würz(1), \\ Betina Pereira de Bem ${ }^{(1)}$, Aike Anneliese Kretzschmar ${ }^{(1)}$ and Leo Rufato ${ }^{(1)}$
}

\begin{abstract}
(1)Universidade do Estado de Santa Catarina, Centro de Ciências Agrárias, Avenida Luiz de Camões, no 2.090, Bairro Conta Dinheiro, CEP 88520-000 Lages, SC, Brazil. E-mail: ricardoufsc@gmail.com, douglaswurz@hotmail.com, betadebem@yahoo.com.br, aikeanneliese@yahoo.com.br, leoruffato@yahoo.com.br ${ }^{(2)}$ Vinícola Legado, Rodovia Raul Azevedo de Macedo, no 5.800, CEP 83606-482 Campo Largo, PR, Brazil. E-mail: marconfilho_jl@yahoo.com.br
\end{abstract}

\begin{abstract}
The objective of this work was to evaluate the effect of different pruning methods on the yield performance and on the oenological potential of Vitis vinifera 'Nebbiolo', cultivated in high-altitude regions of Santa Catarina state, Brazil. The work was carried out in a commercial vineyard located in São Joaquim, SC, during the 2011/2012 and 2014/2015 crop seasons. The treatments consisted of four pruning systems: Guyot, Guyot Arch, and Cazenave (cane pruning systems), and cordon spur pruning. Production, vine balance, and grape composition were evaluated. In the cane pruning systems, a mean production of $2.0 \mathrm{~kg}$ per plant and Ravaz index below 2 were observed, with no change in the composition of the berries. In spur pruned vines, there was production only in 2015, with four bunches every ten plants. Yield and production of the 'Nebbiolo' grapes can be increased without losses of oenological potential, in the high-altitude regions of Santa Catarina state. The tested cane pruning methods are indicated for the growing of 'Nebbiolo' because all methods confer similar yield and vigor to this grapevine.
\end{abstract}

Index terms: Vitis vinifera, Guyot, Guyot Arch, Cazenave, Ravaz index, viticulture.

\section{Métodos de poda sobre o desempenho produtivo e potencial enológico da uva 'Nebbiolo'}

\begin{abstract}
Resumo - O objetivo deste trabalho foi avaliar o efeito de diferentes métodos de poda sobre o desempenho produtivo e o potencial enológico da Vitis vinifera 'Nebbiolo', cultivada em regiões de elevada altitude no Estado de Santa Catarina. O trabalho foi realizado em um vinhedo comercial localizado em São Joaquim, SC, durante os ciclos 2011/2012 e 2014/2015. Os tratamentos consistiram de quatro sistemas de poda: Guyot, Guyot Arch e Cazenave (poda longa) e cordão esporonado (poda curta). Foram avaliadas a produção, o equilíbrio vegeto-produtivo e a composição das uvas. Nos sistemas de poda longa, observou-se produção média de 2,0 kg por planta e índice de Ravaz abaixo de 2, sem alteração da composição das bagas. Nas plantas com poda em cordão esporonado, houve produção apenas em 2015, com quatro cachos a cada dez plantas. A produtividade e a produção da uva 'Nebbiolo' podem ser aumentadas sem perda de potencial enológico, em regiões de altitude do Estado de Santa Catarina. Os métodos de poda longa testados são indicados para o cultivo da uva 'Nebbiolo', porque todos conferem produção similar e vigor ao vinhedo.
\end{abstract}

Termos de indexação: Vitis vinifera, Guyot, Guyot Arch, Cazenave, índice de Ravaz, viticultura.

\section{Introduction}

The high-altitude vineyards of Santa Catarina state, Brazil, are characterized by the production of wine grapes (Vitis vinifera L.) at $900 \mathrm{~m}$ altitude (Vianna et al., 2016). Among its main agronomic peculiarities are the production of red varieties, the use of the vertical shoot-positioned training system, and the cordon spur pruning. Although it is a new region in grapevine cultivation (less than 20 years), some advances have been obtained in the study of scion and rootstocks cultivars adapted to the region (Brighenti et al., 2014; Allebrandt et al., 2015).

'Nebbiolo' is a red wine cultivar from the Piemonte region, located in the northwest of Italy, which is used to produce high-quality wines such as Barolo and Barbaresco. Its vines show high vigor, but its berries have low color in the skin, which generates color instability during wine aging (Guidoni et al., 2008). Studies have been carried in the attempt to increase 
anthocyanin concentration in the skin of 'Nebbiolo' berries, through the manipulation of the leaf area/fruit ratio (Guidoni et al., 2002; Cagnasso et al., 2011).

Pruning is one of the main factors in plant management that allows the winegrower to manipulate vine balance and grape composition. It enables the selection of bearing wood (spurs and canes), thereby influencing the location and development of the canopy (Reynolds \& Vanden Heuvel, 2009). By changing the number of buds and the type of bearing wood, the pruning methods can modify the yield and the leaf area to fruit ratio of grapevines, which also alters grape berries maturation (Miele \& Rizzon, 2013; Greven et al., 2015; Marcon Filho et al., 2016b).

In the high-altitude regions of Santa Catarina, the environmental conditions may favor the production of high-quality and longevity 'Nebbiolo' wines. In these regions, there is a great solar radiation, which promotes the increase of phenolic compounds in the grape skin (Berli et al., 2015). However, the lack of appropriate pruning and canopy managements, associated to the high rainfall (Bem et al., 2016) and high levels of organic matter in the soils (Mafra et al., 2011) promotes the occurrence of unbalanced vineyards with intense vegetative growth and low yield (Borghezan et al., 2011; Brighenti et al., 2011; Zalamena et al., 2013; Marcon Filho et al., 2015). In this scenario, there is a need to identify the management that can overcome these adversities.

The objective of this work was to evaluate the effect of different pruning methods on the yield performance and the oenological potential of 'Nebbiolo' grapevines, cultivated in high-altitude regions of Santa Catarina state.

\section{Materials and Methods}

The study was undertaken in a commercial vineyard located in São Joaquim, SC, Brazil, at $28^{\circ} 15^{\prime \prime} 23 \mathrm{~S}$, $49^{\circ} 57^{\prime} 08^{\prime \prime} \mathrm{W}, 1,230 \mathrm{~m}$ altitude, during the 2011/2012 and 2014/2015 crop season. 'Nebbiolo' grape cultivar (grafted on '1103 Paulsen') was planted in 2004 in a northwest-southeast row orientation, with a 3.0 (row) $\mathrm{x}$ $1.5 \mathrm{~m}$ (vine) spacing. Vines were trained on a vertical shoot position (VSP) and covered with anti-hail protection net.

Treatments consisted of four pruning systems: Guyot, Guyot Arch, and Cazenave (cane pruning types), and cordon spur pruning. The mean number of buds left by treatment was $17,24,45$, and 28 , respectively. The pruning methods were performed by the end of August, in 2011 and 2014. In 2012 and 2013, the treatments were also applied, but evaluations were not performed due to damages caused by the late frost occurrence.

For Guyot pruning system, one one-year-old cane was left per plant, and attached to the wire in parallel with the ground. In the Guyot Arch type, two oneyear-old canes were left per plant, then twisted down, and attached to a wire placed $30 \mathrm{~cm}$ below and parallel to the main wire. Cazenave consisted of a bilateral cordon in which three to four one-year-old canes were left and attached to the second wire (1.5 $\mathrm{m}$ above the ground), forming a $45^{\circ}$ angle to the cordon. In these three pruning systems, one two-bud spur was left for each one-year-old cane. In the spur pruning, vines were trained to a bilateral cordon with two-bud spurs.

The analyzed variables related to yield and vine balance were: yield per vine $(\mathrm{kg})$, number of clusters per vine, cluster weight (g), cane weight (g), pruning weight $\left(\mathrm{g} \mathrm{m}^{-1}\right)$, and the Ravaz index. On the harvest days, which occurred on April 24 $4^{\text {th }}$ and on March $26^{\text {th }}$, in 2012 and in 2015 respectively, the yield and the number of clusters per vine were recorded for each vine, and the cluster weight was obtained through the division of yield by the number of clusters per vine. In August of both years, the pruning weight was recorded for each plant, and divided by the spacing, in order to obtain the pruning mass per linear meter of canopy (Smart et al., 1990). The Ravaz index was obtained by dividing the yield by the pruning weight per plant.

In the 2014/2015 crop season, the leaf area per plant $\left(\mathrm{m}^{2}\right)$ was estimated by multiplying the average leaf area per shoot by the number of shoots per plant. At the time of harvesting, all leaves of ten branches per treatment were collected to measure the leaf area per branch on LI-3000C meter (LI-COR, Inc., Lincoln, NE, USA). The estimated leaf area value for each plant was divided by its respective yield, in order to calculate the ratio of leaf area per fruit area (LA/fruit, $\mathrm{cm}^{2} \mathrm{~g}^{-1}$ ).

The berry composition was accessed only in the cane pruning treatments in both years of study. In the spur-pruned vines, although a little yield was recorded in 2015, there were not enough clusters for a representative sampling for berry analysis. By the sampling of 100 berries per plot, soluble solid content (SS), titratable acidity (TA), $\mathrm{pH}$, total polyphenols, and 
total anthocyanins were analyzed. All berries were manually crushed, one by one, to obtain grape must and skins separately. From the grape must, SS content was determined in a digital temperature-compensated refractometer model PAL-1 (ATAGO, Saitama, Japan), with results expressed in ${ }^{\circ} \mathrm{Brix}$; TA was obtained by titration with $0.1 \mathrm{~N} \mathrm{NaOH}$ until the medium $\mathrm{pH}$ reached 8.2, and the results were expressed in grams per liter of tartaric acid (OIV, 2009); $\mathrm{pH}$ was measured with a potentiometer (Impac, São Paulo, Brasil).

Grape skins underwent an extraction process described by Marcon Filho et al. (2016b). The solution extracts were analyzed for total polyphenol content following the methodology described by Singleton \& Rossi (1965), with the results expressed as milligrams per litre of gallic acid equivalent, and total anthocyanins, according to Rizzon (2010).

The experimental design was a randomized complete block, with five replicates, and six plants per plot. Data were subjected to the analysis of variance at $5 \%$ probability and, when treatment effects were detected, Tukey's range test was performed at 5\% probability.

\section{Results and Discussion}

Cane pruning systems strongly modified the yield parameters of 'Nebbiolo' grapevine (Table 1). The yield performance in vines which received the cane pruning method (Guyot, Guyot Arch, and Cazenave) were similar to each other; however, all of them were superior to the plants that received spur pruning. In
Guyot, Guyot Arch, and Cazenave, the mean yield per vine ranged between 1.9 and $2.1 \mathrm{~kg}$ in the 2012 and 2015 harvests, respectively. In all treatments, the yield per vine was related to the number of clusters per vine and the cluster weight. Although there were no differences between cane pruning treatments in the first evaluated cycle, vines produced fewer but heavier clusters in the Guyot Arch treatment, than in the other cane pruning methods, in the 2015 cycle. Spur-pruned vines were significantly inferior in number of clusters and cluster weight than cane-pruned vines. There was no production in 2012, and an insignificant production of four clusters every 10 plants was observed in the 2015 crop. In addition, clusters produced in spurpruned vines were $36 \%$ lighter than the ones from cane-pruned vines.

Yield found in this experiment was considerably lower in comparison to those of other studies (Wolf \& Miller, 2001; Guidoni et al., 2002; Shellie, 2007; Guidoni et al., 2008). 'Nebbiolo' is known for its low fertility in basal buds ( $1^{\text {st }}$ to $5^{\text {th }}$ bud); therefore, in order to increase its production, cane pruning should be performed (Rosa et al., 2014). However, when a small production was observed in spur-pruned vines, it was $97 \%$ lower than the yield of cane-pruned ones, whereas in a study carried out in the USA, this same comparison showed a reduction of $58 \%$ (Wolf \& Miller, 2001). In addition, cane-pruned vines yielded $50 \%$ less than the yields observed in other studies on

Table 1. Yield components and vigor of 'Nebbiolo' grapevines subjected to different pruning methods, in São Joaquim, SC, Brazil, in the 2012 and 2015 cycles $^{(1)}$.

\begin{tabular}{|c|c|c|c|c|c|}
\hline \multirow[t]{2}{*}{ Variable } & \multirow[t]{2}{*}{ Cycle } & \multicolumn{4}{|c|}{ Pruning method } \\
\hline & & Guyot & Guyot Arch & Cazenave & Spur cordon \\
\hline \multirow{2}{*}{$\begin{array}{l}\text { Yield per vine } \\
(\mathrm{kg})\end{array}$} & 2012 & $1.8 \pm 0 \mathrm{a}$ & $2.2 \pm 0.4 \mathrm{a}$ & $1.7 \pm 0.7 \mathrm{a}$ & $0.00 \pm 0 \mathrm{~b}$ \\
\hline & 2015 & $2.1 \pm 0 \mathrm{a}$ & $1.9 \pm 0.4 \mathrm{a}$ & $2.4 \pm 0.5 \mathrm{a}$ & $0.06 \pm 0.1 \mathrm{~b}$ \\
\hline \multirow{2}{*}{$\begin{array}{l}\text { Clusters } \\
\text { per vine }\end{array}$} & 2012 & $11 \pm 1 \mathrm{a}$ & $12 \pm 1 \mathrm{a}$ & $9 \pm 2 \mathrm{a}$ & $0.0 \pm 0 \mathrm{~b}$ \\
\hline & 2015 & $15 \pm 2 \mathrm{a}$ & $10 \pm 2 b$ & $16 \pm 3 \mathrm{a}$ & $0.4 \pm 0.5 \mathrm{c}$ \\
\hline \multirow{2}{*}{$\begin{array}{l}\text { Cluster weight } \\
\text { (g) }\end{array}$} & 2012 & $177.8 \pm 8.1 \mathrm{a}$ & $185.3 \pm 40.6 \mathrm{a}$ & $187.2 \pm 56.5 \mathrm{a}$ & $0.0 \pm 0 \mathrm{~b}$ \\
\hline & 2015 & $136.1 \pm 17.2 \mathrm{ab}$ & $181.6 \pm 28.0 \mathrm{a}$ & $155.8 \pm 22.2 \mathrm{ab}$ & $108.8 \pm 15.9 \mathrm{~b}$ \\
\hline \multirow{2}{*}{$\begin{array}{l}\text { Pruning weight } \\
\left(\mathrm{g} \mathrm{m}^{-1}\right)\end{array}$} & 2012 & $893 \pm 148 \mathrm{a}$ & $1,009 \pm 148 \mathrm{a}$ & $1,013 \pm 76 \mathrm{a}$ & $1,113 \pm 277 \mathrm{a}$ \\
\hline & 2015 & $721 \pm 197 b$ & $663 \pm 156 b$ & $1,102 \pm 199 \mathrm{a}$ & $868 \pm 36 \mathrm{ab}$ \\
\hline \multirow{2}{*}{$\begin{array}{l}\text { Ravaz index } \\
\left(\mathrm{kg} \mathrm{kg}^{-1}\right)\end{array}$} & 2012 & $1.3 \pm 0.2 \mathrm{a}$ & $1.4 \pm 0.4 \mathrm{a}$ & $1.1 \pm 0.3 \mathrm{a}$ & $0 \pm 0 \mathrm{~b}$ \\
\hline & 2015 & $2.1 \pm 0.7 \mathrm{a}$ & $1.9 \pm 0.7 \mathrm{a}$ & $1.7 \pm 0.5 \mathrm{a}$ & $0.1 \pm 0.1 \mathrm{~b}$ \\
\hline \multirow{2}{*}{$\begin{array}{l}\text { Leaf area per fruit } \\
\left(\mathrm{cm}^{2} \mathrm{~g}^{-1}\right)\end{array}$} & 2012 & - & - & - & - \\
\hline & 2015 & $15.7 \pm 2 \mathrm{~b}$ & $19 \pm 5 \mathrm{~b}$ & $20 \pm 5 b$ & $299 \pm 6 \mathrm{a}$ \\
\hline
\end{tabular}

${ }^{(1)}$ Means followed by equal letters, in the rows, do not differ by the Tukey's test, at $5 \%$ probability. ${ }^{(2)} Y$ ield/pruning weight per plant. 
cane-pruned 'Nebbiolo' vines (Wolf \& Miller, 2001; Guidoni et al., 2002, 2008; Shellie, 2007).

The pruning weight ranged between 663 and 1,113 g per linear meter of canopy. Pruning weight is an indicative of the vineyard's vigor, and values between 300 and $600 \mathrm{~g} \mathrm{~m}^{-1}$ indicate well balanced vines (Smart et al., 1990). In the yield/pruning weight ratio, known as the Ravaz index, the highest values (between 1.1 and 2.1) were observed in cane pruning treatments, and the lowest values ( 0.0 and 0.1$)$, in spur-pruned vines. Either way, all values were below the ideal one described in the literature, considered to be between 5 and 10 (Smart et al., 1990). Ravaz index values below 5 do not favor the increase of wine grape quality, and indicates that plants invested a bigger amount of energy in shoot growth rather than in cluster development. The low values found in the present study corroborate those of other studies performed with different cultivars for high-altitude regions of Santa Catarina (Borghezan et al., 2011; Brighenti et al., 2011; Marcon Filho et al., 2015), and can be explained by the limited number of fertile buds in vigorous plants, which led to a low number of cluster per plant and to an excessive shoot growth.

The leaf area to fruit load ratio in cane-pruned vines varied from 15.7 to $20 \mathrm{~cm}^{2} \mathrm{~g}^{-1}$, and the value observed in spur-pruned vines was more than 10 times higher. According to the literature, values between 7 and 14 $\mathrm{cm}^{2} \mathrm{~g}^{-1}$ represent well-balanced grapevines (Kliewer \& Dokoozlian, 2005), which allows of an adequate

Table 2. Total soluble solids, titratable acidity, $\mathrm{pH}$, total polyphenols and anthocyanins of 'Nebbiolo' grapes from vines subjected to different pruning methods, in São Joaquim, SC, Brazil, in the 2012 and 2015 cycles $^{(1)}$.

\begin{tabular}{|c|c|c|c|c|}
\hline \multirow[t]{2}{*}{ Variable } & \multirow[t]{2}{*}{ Cycle } & \multicolumn{3}{|c|}{ Pruning method } \\
\hline & & Guyot & Guyot Arch & Cazenave \\
\hline \multirow{2}{*}{$\begin{array}{l}\text { Total soluble solids } \\
\left({ }^{\circ} \text { Brix }\right)\end{array}$} & 2012 & $23.7 \pm 0.2$ & $23.4 \pm 0.7$ & $22.8 \pm 1.1$ \\
\hline & 2015 & $21.9 \pm 0.3$ & $21.3 \pm 0.7$ & $21.9 \pm 0.6$ \\
\hline \multirow{2}{*}{$\begin{array}{l}\text { Titratable acidity } \\
\left(\mathrm{g} \text { tartaric acid } \mathrm{L}^{-1}\right)\end{array}$} & 2012 & $10.6 \pm 1.1$ & $9.4 \pm 0.7$ & $9.6 \pm 1.8$ \\
\hline & 2015 & $11.6 \pm 0.5$ & $12.7 \pm 0.5$ & $11.6 \pm 0.8$ \\
\hline \multirow{2}{*}{$\mathrm{pH}$} & 2012 & $2.85 \pm 0.03$ & $2.91 \pm 0.04$ & $2.92 \pm 0.02$ \\
\hline & 2015 & $3.10 \pm 0.01$ & $3.10 \pm 0.04$ & $3.12 \pm 0.02$ \\
\hline \multirow{2}{*}{$\begin{array}{l}\mathrm{TP}\left(\mathrm{mg} \mathrm{L}^{-1} \text { galic }\right. \\
\text { acid equivalent) }\end{array}$} & 2012 & $1,236 \pm 110$ & $1,225 \pm 128$ & $1,124 \pm 134$ \\
\hline & 2015 & $2,230 \pm 207$ & $1,915 \pm 138$ & $1,880 \pm 278$ \\
\hline \multirow{2}{*}{$\begin{array}{l}\text { TA (mg L-1 malvidin } \\
\text {-3-glicoside) }\end{array}$} & 2012 & $447 \pm 86$ & $406 \pm 109$ & $404 \pm 66$ \\
\hline & 2015 & $1,189 \pm 117$ & $874 \pm 72$ & $913 \pm 95$ \\
\hline
\end{tabular}

(1)Means in the rows do not differ by the Tukey's test, at $5 \%$ probability. $\mathrm{TP}$, total polyphenols; TA, total anthocyanins. sugar content in the berries, and starch reserve accumulation in the bearing woods. Spur-pruned vines were extremely unbalanced due to the almost complete lack of grape production. The values found in cane pruning treatments were slightly higher than the ideal one mentioned above. However, in Italy, LA/fruit ratio around $20 \mathrm{~cm}^{2} \mathrm{~g}^{-1}$ was considered to be the optimum for 'Nebbiolo' wine grapes (Guidoni et al., 2008). In high-altitude regions of Santa Catarina state, the ideal $\mathrm{LA} /$ fruit ratio have been studied for a few different cultivars. For 'Malbec', it was found to be around 24,5 $\mathrm{cm}^{2} \mathrm{~g}^{-1}$ (Silva et al., 2008); for 'Syrah', it was $16 \mathrm{~cm}^{2} \mathrm{~g}^{-1}$ (Silva et al., 2009); and for 'Merlot', $23 \mathrm{~cm}^{2} \mathrm{~g}^{-1}$ was the value observed (Borghezan et al., 2011).

Cane pruning methods did not influence the composition of 'Nebbiolo' grape berries (Table 2). Despite the low yield and the high vigor, the berry composition reached values of soluble solids between 21.3 and $23.7^{\circ}$ Brix, which represent 12.4 to $14.1 \%$ alcoholic content potentials, in addition to being in accordance with values found in the literature (Wolf \& Miller, 2001; Guidoni et al., 2002, 2008; Cagnasso et al., 2011). The values of acidity and $\mathrm{pH}$ averaged $10.9 \mathrm{~g} \mathrm{~L}^{-1}$ and 3.0, respectively, and corroborate those found by Cagnasso et al. (2011) in 'Nebbiolo' berries in the Piemonte region. In the 2012 cycle, the climatic conditions such as low rainfall contributed for a higher accumulation of soluble solids in the berries than the observed ones in the 2015 cycle. The two months (March and April) preceding the 2012 harvest were dryer than the historical average, according to climatic data collected by Brighenti et al. (2014). These conditions allowed a one-month longer period of ripening, in comparison to the 2015 cycle that had a rainy period during February and March.

The phenolic content was not affected by the pruning method (Table 2). Total anthocyanin contents were also similar between treatments. These results corroborate the findings in the literature. In a comparison of four training systems (simple Guyot, double Guyot, horizontal spurred cordon, and vertical spurred cordon), little or no impact occurred on grape or wine composition, and the sensory analysis showed no differences among systems (Peterlunger et al., 2002). In a five-year study with 'Barbera' grown under four different training systems, must composition at harvest was similar among spur-pruned low-cordon, single high-wire cordon, and single Guyot systems, while split double Guyot produced grapes of overall 
inferior quality (Bernizzoni et al., 2009). Total phenolic contents were lower than those found by Guidoni \& Ferrandino (2006), but the total anthocyanin contents were similar to or greater than those found in 'Nebbiolo' berries in its traditional growing region of Italy (Guidoni \& Ferrandino, 2005/2006; Guidoni et al., 2008; Rolle et al., 2012).

\section{Conclusions}

1. The cane pruning methods - Guyot, Guyot Arch, and Cazenave - are suitable to be applied in 'Nebbiolo' vines because they confer similar yield and vigor to this grapevines; in high-altitude regions, these methods do not affect the 'Nebbiolo' berry composition, whose oenological potential is similar to those observed in the Nebbiolo's traditional producing regions.

2. Spur pruning is not indicated for 'Nebbiolo' grapevines because it confers insignificant or no production.

\section{Acknowledgments}

To Coordenação de Aperfeiçoamento de Pessoal de Nível Superior (Capes), to Fundação de Amparo à Pesquisa e Inovação do Estado de Santa Catarina (Fapesc), and to Conselho Nacional de Desenvolvimento Científico e Tecnológico (CNPq), for the scholarships granted and for financial support.

\section{References}

ALLEBRANDT, R.; MARCON FILHO, J.L.; BEM, B.P. de; WÜRZ, D.A.; BRIGHENTI, A.F.; KRETZSCHMAR, A.A.; RUFATO, L. Fenologia da variedade Merlot produzida sobre três porta-enxertos em elevadas altitudes de Santa Catarina. Revista Brasileira de Viticultura e Enologia, v.7, p.36-43, 2015.

BEM, B.P. de; BOGO, A.; EVERHART, S.E.; CASA, R.T.; GONÇALVES, M.J.; MARCON FILHO, J.L.; RUFATO, L.; SILVA, F.N. da; ALLEBRANDT, R.; CUNHA, I.C. da. Effect of four training systems on the temporal dynamics of downy mildew in two grapevine cultivars in Southern Brazil. Tropical Plant Pathology, v.41, p.370-379, 2016. DOI: 10.1007/s40858-016-0110-8.

BERLI, F.J.; ALONSO, R.; BELTRANO, J.; BOTTINI, R. Highaltitude solar UV-B and abscisic acid sprays increase grape berry antioxidant capacity. American Journal of Enology and Viticulture, v.66, p.65-72, 2015. DOI: 10.5344/ajev.2014.14067.

BERNIZZONI, F.; GATTI, M.; CIVARDI, S.; PONI, S. Longterm performance of Barbera grown under different training systems and within-row vine spacings. American Journal of Enology and Viticulture, v.60, p.339-348, 2009.
BORGHEZAN, M.; PIT, F.A.; GAVIOLI, O.; MALINOVSKI, L.I.; SILVA, A.L. da. Efeito da área foliar sobre a composição da uva e a qualidade sensorial dos vinhos da variedade Merlot (Vitis vinifera L.) cultivada em São Joaquim, SC, Brasil. Ciência e Técnica Vitivinícola, v.26, p.1-9, 2011.

BRIGHENTI, A.F.; RUFATO, L.; KRETZSCHMAR, A.A.; SCHLEMPER, C. Desempenho vitivinícola da Cabernet Sauvignon sobre diferentes porta-enxertos em região de altitude de Santa Catarina. Revista Brasileira de Fruticultura, v.33, p.96-102, 2011. DOI: 10.1590/S0100-29452011005000039.

BRIGHENTI, A.F.; SILVA, A.L. da; BRIGHENTI, E.; PORRO, D.; STEFANINI, M. Desempenho vitícola de variedades autóctones italianas em condição de elevada altitude no Sul do Brasil. Pesquisa Agropecuária Brasileira, v.49, p.465-474, 2014. DOI: 10.1590/S0100-204X2014000600008.

CAGNASSO, E.; TORCHIO, F.; GERBI, V.; RÍO SEGADE, S.; GIACOSA, S.; ROLLE, L. Evolution of the phenolic content and extractability indices during ripening of Nebbiolo grapes from the Piedmont growing areas over six consecutive years. South African Journal of Enology and Viticulture, v.32, p.229-241, 2011. DOI: $10.21548 / 32-2-1383$.

GREVEN, M.M.; NEAL, S.M.; HALL, A.J.; BENNETT, J.S. Influence of retained node number on Sauvignon Blanc grapevine phenology in a cool climate. Australian Journal of Grape and Wine Research, v.21, p. 290-301, 2015. DOI: 10.1111/ajgw.12122.

GUIDONI, S.; ALLARA, P.; SCHUBERT, A. Effect of cluster thinning on berry skin anthocyanin composition of Vitis vinifera cv. Nebbiolo. American Journal of Enology and Viticulture, v.53, p.224-226, 2002.

GUIDONI, S.; FERRANDINO, A. La gestione agronomica del vigneto di 'Nebbiolo'. Quaderni di Scienze Viticole ed Enologiche, v.28, p.115-123, 2005/2006.

GUIDONI, S.; FERRANDINO, A.; NOVELLO, V. Effects of seasonal and agronomical practices on skin anthocyanin profile of Nebbiolo grapes. American Journal of Enology and Viticulture, v.59, p.22-29, 2008.

KLIEWER, W.M.; DOKOOZLIAN, N.K. Leaf area/crop weight ratios of grapevines: Influence on fruit composition and wine quality. American Journal of Enology and Viticulture, v.56, p.170-181, 2005.

MAFRA, M.S.H.; CASSOL, P.C.; MIQUELLUTI, D.J.; ERNANI, P.R.; GATIBONI, L.C.; FERREIRA, E.Z.; BARROS, M. de; ZALAMENA, J.; GROHSKOPT, M.A. Atributos químicos do solo e estado nutricional de videira Cabernet Sauvignon (Vitis vinifera L.) na Serra Catarinense. Revista de Ciências Agroveterinárias, v.10, p.44-53, 2011.

MARCON FILHO, J.L.; ALLEBRANDT, R.; WÜRZ, D.A.; BEM, B.P. de; MACEDO, T.A. de; KRETZSCHMAR, A.A.; RUFATO, L. Cane pruning on Chardonnay grapevine in the highaltitude regions of Southern Brazil. BIO Web of Conferences, v.7, art. 01036, 2016. DOI: 10.1051/bioconf/20160701036.

MARCON FILHO, J.L.; HIPÓLITO, J. de S.; MACEDO, T.A. de; KRETZSCHMAR, A.A.; RUFATO, L. Raleio de cachos sobre o potencial enológico da uva 'Cabernet Franc' em duas safras. 
Ciência Rural, v.45, p.2150-2156, 2015. DOI: 10.1590/0103$8478 \mathrm{cr} 20140995$.

MIELE, A.; RIZZON, L.A. Intensidades da poda seca e do desbaste de cacho na composição da uva Cabernet Sauvignon. Revista Brasileira de Fruticultura, v. 35, p.1081-1092, 2013. DOI: 10.1590/S0100-29452013000400020.

OIV. Organisation Internationale de la Vigne et du Vin. Recueil des méthodes internationales d'analyse des vins et des mouts. Paris, 2009. v.1, 368p.

PETERLUNGER, E.; CELOTTI, E.; DALT, G.D.; STEFANELLI, S.; GOLLINO, G.; ZIRONI, R. Effect of training system on Pinot Noir grape and wine composition. American Journal of Enology and Viticulture, v.53, p.14-18, 2002.

REYNOLDS, A.G.; VANDEN HEUVEL, J.E. Influence of grapevine training systems on vine growth and fruit composition: a review. American Journal of Enology and Viticulture, v.60, p.251-268, 2009.

RIZZON, L.A. (Ed.). Metodologia para análise de vinho. Brasília: Embrapa Informação Tecnológica, 2010. 120p.

ROLLE, L.; TORCHIO, F.; GIACOSA, S.; RÍO SEGADE, S.; CAGNASSO, E.; GERBI, V. Assessment of physicochemical differences in Nebbiolo grape berries from diferent production areas and sorted by flotation. American Journal of Enology and Viticulture, v.63, p.195-204, 2012. DOI: 10.5344/ajev.2012.11069.

ROSA, A.M.; PESCADOR, R.; SILVA, A.L. da; BRIGHENTI, A.F.; BRUNETO, G. Fertilidade e reserva de carbono e nitrogênio em gemas de ramos das viníferas 'Cabernet Sauvignon' e 'Nebbiolo'. Revista Brasileira de Fruticultura, v.36, p.576-585, 2014. DOI: 10.1590/0100-2945-198/13.

SHELLIE, K.C. Viticultural performance of red and white wine grape cultivars in southwestern Idaho. HortTechnology, v.17, p.595-603, 2007.
SILVA, L.C. da; KRETZSCHMAR, A.A.; RUFATO, L.; BRIGHENTI, A.F.; SCHLEMPER, C. Níveis de produção em vinhedos de altitude da cv. Malbec e seus efeitos sobre os compostos fenólicos. Revista Brasileira de Fruticultura, v.30, p.675-680, 2008. DOI: 10.1590/S0100-29452008000300019.

SILVA, L.C. da; RUFATO, L.; KRETZSCHMAR, A.A.; MARCON FILHO, J.L. Raleio de cachos em vinhedos de altitude e qualidade do vinho da cultivar Syrah. Pesquisa Agropecuária Brasileira, v.44, p.148-154, 2009. DOI: 10.1590/S0100204X2009000200006.

SINGLETON, V.L.; ROSSI, J.A. Colorimetry of total phenolics with phosphomolybdic - phosphotungstic acid reagents. American Journal of Enology and Viticulture, v.16, p. 144-158, 1965.

SMART, R.E.; DICK, J.K.; GRAVETT, I.M.; FISHER, B.M. Canopy management to improve grape yield and wine quality principles and practices. South African Journal of Enology and Viticulture, v.11, p.3-17, 1990. DOI: 10.21548/11-1-2232.

VIANNA, L.F.; MASSIGNAN, A.M.; PANDOLFO, C.; DORTZBACH, D.; VIEIRA, V.F. Caracterização agronômica e edafoclimática dos vinhedos de elevada altitude. Revista de Ciências Agroveterinárias, v.15, p.215-226, 2016. DOI: $10.5965 / 223811711532016215$.

WOLF, T.K.; MILLER, M.K. Crop yield, fruit quality, and winter injury of 12 red-fruited wine grape cultivars in Northern Virginia. Journal of the American Pomological Society, v.55, p.241-250, 2001.

ZALAMENA, J.; CASSOL, P.C.; BRUNETTO, G.; GROHSKOPF, M.A.; MAFRA, M.S.H. Estado nutricional, vigor e produção em videiras cultivadas com plantas de cobertura. Revista Brasileira de Fruticultura, v.35, p.1190-1200, 2013. DOI: 10.1590/S010029452013000400030 .

Received on February 15, 2017 and accepted on April 17, 2017 